DOI: 10.46340/eppd.2021.8.2.3

\author{
Keti Jijeishvili, Doctor of Political Sciences \\ ORCID ID: https://orcid.org/0000-0002-1543-6988 \\ Georgian Technical University, Tbilisi, Georgia \\ Giorgi Chkhikvishvili, Doctor of Social Sciences \\ ORCID ID: $h$ ttps://orcid.org/0000-0002-2080-858X \\ Georgian Technical University, Tbilisi, Georgia
}

\title{
STRATEGIC VECTORS OF RUSSIAN FOREIGN POLICY TOWARDS GEORGIA
}

The most serious threats and challenges facing Georgia, which hinder the state development, hold up the country's Euro-Atlantic integration, the de-occupation of the occupied territories, and their reintegration, mainly come from Russia. Russia's foreign policy strategy in Georgia was historically based on the implementation of the "carrot and stick" policy. This method was used brilliantly by the Russian Imperial Gendarmerie and diplomacy during the conquest of the Caucasus when the fierce Ermolov was replaced by the soft and educated Vorontsov. And later, after the restoration of independence, despite the loss of 20 percent of the territories of Georgia, as a result of the war and unilaterally declare of the Republic of Abkhazia and the Republic of South Ossetia as independent states, created with the unilateral act by Moscow, anti-Russian sentiment in Georgia did not diminish. Partly modernized Russia has replaced military components with nonviolent forms of influence to ennoble rough force. These technologies, known as Russia's "soft power" policies, have been further refined over time, institutionalized at the state level, thus making its use as a tool of political struggle completely formalized, and it has continued to be used in Georgia with enviable effectiveness. The narratives of Russian propaganda in Georgia are mainly represented by three dominant viewpoints, which are constantly heard by the pro-Russian media: 1. Religion as a basis for unity; 2 . National identity - public discourses based on historical past and shared values, and 3. Cultural proximity - the experience of unified cultural processes. Based on these narratives, a whole series of political myths is created and generated, which aims, on the one hand, to establish the messianic role of Russia (or its leader) and, on the other hand, to diminish the Western political system and values.

There is a growing debate in the international arena about developing appropriate response mechanisms to existing challenges. Effective steps have also been taken by the international community to reduce the threat of growing Russian influence in the long term perspective. However, this requires Georgia to pursue the right policies towards existing threats and challenges - to effectively develop and implement Euro-Atlantic integration and de-occupation strategies based on the opportunities created, to develop effective institutional and legal frameworks for state security policy-making, and to establish an effective practice.

Keywords: Political myth, political narrative, propaganda, "soft power", "hard power", moral relativism, military aggression, cultural closeness.

The issue of Russia is beating like a "naked nerve" in the Georgian consciousness. It can be said that there are few neighboring countries in the history of relations between modern states, whose coexistence was overloaded with dramatic events, as in the example of Georgia-Russia. Unfortunately, at the scientific level in Georgia, the foreign policy vectors of "Russia on the march" (according to H. Kissinger) are less studied.

The idea of creating an Orthodox kingdom in the XV century was inherited by the great Russian prince Ivan II from fallen Byzantium. He declared himself as the heir of Constantinople. The idea that Moscow is the Third Rome since then has become the core of Russian statehood and its ideological basis.

Peter the Great received the status of Western emperor instead of the Russian "Tsar" and left a legacy to his descendants: "I saw Russia as a stream, but I left it as a river; My heirs will turn it into a sea that will 
fertilize impoverished Europe". His successors, indeed, managed to turn the stream into a sea: by the 1980s, the territory of the vast Russian empire was covered 22.4 million square kilometers (one-sixth of the earth), and the population, according to the 1897 census, was 128.2 million people, but they failed to turn Russia into "west". Despite constant efforts, it only has become possible for Russia to be a transformed, modernized East. N. Berdyaev wrote: "The Russian people are neither pure Europeans nor pure Asians. Russia is a whole part of the world, huge East-West, it unites two worlds; In the soul of a Russian man there are always two origins, Eastern and Western"1. "In Europe, we were rovers and slaves and in Asia, we appeared as masters. In Europe we are Tatars, and in Asia, we are Europeans as well" ${ }^{2}$ - wrote N. Dostoevsky. It is true that Peter I was the first to cut a window in Europe with the founding of St. Petersburg, but the beam of light coming from this one window penetrated Georgia late. "In the window cut by Peter the Great, although it was strongly illuminated by light from Europe, there is still a lot of oasis of darkness left," wrote Akaki Tsereteli ${ }^{3}$. The light of civilization, refracted through the Russian prism, could not penetrate the invisible space of the empire. It failed to play the role that European empires played in the history of the former colonial peoples, namely, respect for Western values, recognition of the rule of law, adaptation to the principles of liberalism, and the formation of other qualities that made the transformation of these people into post-colonial transitions easier. S. Huntington focuses on this vector when he considers the "experience of being a British colony" as a contributing factor to the democratization process ${ }^{4}$.

The answer to Niko Berdzenishvili's rhetorical question - "Did Russia come to the Caucasus or did Erekle II bring him?" represents Panin's secret correspondence to General Totleben, the Russian envoy to Georgia: "You should try to arrange things in Georgia so that everything happens "under our leadership", and the Georgians themselves think that they are carrying out their government's decree, and the government itself is convinced that everything happens under its will, in one word, every our desire should be enforced, but in such a way that the soul is from here and the body is Georgian"5. If we carry out a political analysis of modern Georgian political thought, we will be convinced that the Russian soul and the Georgian body are an eternal and interminable topic on the proscenium of Georgian politics.

But in the preamble of the Treaty of Georgievsk, as well as in the book of oaths sent to Kakheti, the Georgian king is represented as a petitioner. The political processes in so-called South Ossetia and Abkhazia are a modernized version of such a policy today. So, outwardly, Georgia "voluntarily became part of the empire", although perhaps more important and defining in Russian-Georgian relations was not how Russians and Georgians love or hate each other, but the coincidence of the interests of these countries at some point in history. Historical justice requires to note that the Russian takeover, contrary to the tsarist government's imperial aspirations, has had some positive consequences, namely, after Russia's establishment the Georgian nation has achieved national and territorial integrity and social and economic prosperity in exchange for the freedom, but finally, it has become an obstacle to the progressive development of the nation. Instead of accelerating European development, our country has taken the opposite form of advancement. At the same time, historically, Russia has always been a state whose trust was risky. If we borrow Winston Churchill, "the price of the agreement with the Russians does not exceed the price of the sheet of paper on which it is printed". Indeed, it numerously violated the agreement and broke its word. Russian Emperor Alexander I turned the Treaty of Georgievsk into a scrap of paper - not only did he not defend and protect Georgia, but he conquered it himself: abolished the rule of Georgian kings and autocephaly and enslaved the country for a long time. He turned the agreement signed on May 7, 1920, between Russia and Georgia into a scrap of paper as well. In just a century and a half, since dominate Georgia, Russia (including the USSR) has fought 11 major wars with a total duration of more than 25 years. Seven of them crossed the front line through Georgia. The result is easy to imagine. The same fate befell the famous Medvedev-Sarkozy treaty. It should be noted, however, that the history of diplomacy knows a precedent when, under the international influence, Russia was forced to acknowledge the legitimate inadmissibility of its foreign policy strategy to other states and agree to its fundamental adjustment. We are referring to the position of Count Shuvalov, the Russian ambassador to London at the Congress of Berlin in June 1878, who was one of the first to recognize the fairness of the famous memorandum of the British Foreign Secretary Lord Salisbury, which was convincingly justified why The San Stefano Peace Treaty was objectively unacceptable for European peace and publicly supported the

\footnotetext{
${ }^{1}$ Бердяев, Н. (1971). Русская идея. Париж.

2 Достоевский, Ф. М. (1884). Полный сборник сочинений. Москва, 27.

${ }^{3}$ Tsereteli, A. (1990). Records in five volumes. Tbilisi, V. 128.

${ }^{4}$ Dundua, S. (2001). Liberal Democracy and the State Building Process in Contemporary Georgia. Tbilisi, 41.

${ }^{5}$ Javakhishvili, I., Surguladze, P. (1989). List. Historical parity. Tbilisi, 109.
} 
revision of the truce with Turkey, which was unprecedentedly favorable for Russia. It is true that this fact, unfortunately, is the only one in the political history of Russia, but the logic of the development of globalization at the present stage gives a chance that in case of mobilization of international public opinion around the interests of the Georgian state, this fact only will not remain as a precedent.

Since the restoration of Georgia's independence, the Russian Federation has used various economic levers to maintain its influence. The most effective of these economic levers were: energy dependence, closure of the market of the Russian Federation, restriction of labor migration, control of remittances, and tightening of the visa regime. In terms of economic coercion, the Russian Federation used all its leverage against Georgia, in particular, cut off Georgia's natural gas and electricity supply, closed the market for Georgian agricultural products, introduced visa bans, and established certain mechanisms to limit remittances from Russian Federation to Georgia. Most of these levers have been in operation since 2004. These measures have seriously damaged the Georgian economy, but have not led to its collapse. One circumstance should be emphasized, namely: the Georgian government pursued a very unambiguous policy towards Euro-Atlantic integration during this period and received considerable assistance from the West. Russia's leverage has weakened in Georgia. Diplomatic relations were discontinued; Human contact has decreased; the Border movement was complicated; Cultural and educational exchange programs were discontinued; Business relationships were restricted; All this has led to alienation not only between the governments but also between the people of these two countries.

With this background, at the traditional Munich Security Conference on February 10, 2007, in the form of the "Putin Doctrine", Russia announced its intention to become the chief architect of the European security system. Its changed tactics had a tragic effect on the Georgian state. If in the 1990s Russia was encouraging conflicts in Abkhazia and Shida Kartli from outside to bring Georgia under its influence and to quell Western aspirations, on August 8, 2008, it directly crossed the Georgian border and launched a military intervention. An armed conflict called the Russian-Georgian war has broken out between Georgian troops and Ossetian separatists backed up by Russian troops in the Tskhinvali region. Ronald d. Asmus in his book "A Little War That Shook the World"1 names the issue of giving MAP as a condition for promoting war. According to him, the mistake of the US and Europe was that they did not properly assess and were not ready to take into account the fact that Moscow would use this situation to its advantage.

Also, one of the causes of the war as Ronald d. Asmus cites was the recognition of Kosovo's independence by Western diplomacy in the spring of 2008, after which Russia also recognized the independence of South Ossetia and Abkhazia on August 26, 2008, due to the "domino effect". With the mediation of France, which was the President of the European Union at that time, the conflict parties reached a ceasefire agreement on August 12, which was signed by Georgia in Tbilisi on August 15, and by Russia in Moscow on August 16. On August 12, Russian President Dmitry Medvedev issued a ceasefire order and signed a six-point agreement ("Sarkozy-Medvedev-Saakashvili"), part of which is still unfulfilled, namely, no withdrawal of Russian troops from pre-conflict positions in Georgia.

As a result of this military aggression, international organizations and some states paid great attention to certain details, such as which side fired first or how proportionate the military forces was, but such an approach has gradually changed and since 2010 the assessments towards the main problem have emerged that Russian troops Being on the territory of Georgia is "illegal occupation". This is confirmed not only by the use of this term by individual countries towards the occupied regions of Georgia but also by an international organization such as the NATO Parliamentary Assembly, which has adopted a special resolution on Georgia (Resolution \# 382). 412 people were killed and 1747 Georgian citizens were wounded, 133 thousand Georgians left their homes as a result of the war ${ }^{2}$. Eventually, as a result of this war, Georgia lost $20 \%$ of its territory, the Kodori Gorge, known as Upper Abkhazia, the Liakhvi Gorge, and the Akhalgori district. Despite the tragic consequences of the war and the unilateral recognition of "The Republic of Abkhazia" and "The Republic of South Ossetia" by Moscow on the territory of Georgia, the anti-Russian sentiment in Georgia has not diminished. Putin realized that he could not turn Georgian society back to Russia through war and the only use of hard power. That is why he changed the policy. Partially modernized Russia replaced military components with nonviolent forms of influence to ennoble rough force, which has been refined over time and continued to be used with enviable effectiveness in Georgia, known as Russia's "soft power" policy.

\footnotetext{
${ }^{1}$ Asmus, D. (2010). A Little war that shook the world. Tbilisi, 187.

${ }^{2}$ Ibid, 49.
} 
The policy of "soft power" is one of the modernist theories today and is slowly becoming a determinant of international relations. The attractiveness, effect, and importance of "soft power" in international relations are gradually increasing due to its cheapness and importance, because "hard power", as time goes on, becomes a more and more expensive pleasure and consumes a lot of budget funds.

The concept of Soft Power is thought to have been developed by Joseph Nye, an American scientist and professor at Harvard University, in 2004, in his book "Soft Power: The Means to Success in World Politics"1. It is true that "soft power" is a relatively new term, but it is not new essentially. This method was used brilliantly by the Russian Imperial Gendarmerie and diplomacy during the conquest of the Caucasus when the fierce Ermolov was replaced by the soft and educated Vorontsov. Akaki Tsereteli remembered how warmly and respectfully the Georgians, who came to St. Petersburg, treated Vorontsov's widow. Each of them felt obliged to invite her and personally expressed their gratitude. Over time, Russia further refined the concept of effective replacement of "hard power" with "soft power" and continued to use it in Georgia with enviable efficiency ${ }^{2}$.

The "soft power" for Russia is one of the active tools needed to create the necessary ideological and political platform, which the Kremlin uses openly and very intensively. Russia has institutionalized "soft power" at the state level, thus formalizing its use as a tool of political struggle.

Successful move towards Western integration made Georgia a target for Russian propaganda and disinformation campaigns ${ }^{3}$. It is believed that such campaigns are aimed at weakening Georgia's European and Euro-Atlantic integration, as well as destroying the trust of Georgian political institutions and citizens towards Georgia, as a country capable of democratically governing itself.

The concept of "soft power" was reflected in Russia's post-2007 state security strategies and foreign policy concepts. Putin also speaks of Russia's "soft power" in his 2012 article, "Russia and the Changing World", which has nothing in common with Joseph Nye's classic definition. If the American scientist considered "soft power" as a mechanism for achieving strategic goals, by creating an attractive and successful model, "soft power" with Putin has a completely different definition. He speaks of "a mechanism for achieving foreign policy goals without the use of force, intervention and aggressive campaigning" 4 . But in the same letter, the Russian president focuses on non-governmental organizations as sources of separatism and extremism, which only bring destabilization to the countries (as an example of the "Arab Spring"). Another important fact was the statement of General Gerasimov, who openly stated that political goals in the 21 st century can be achieved through non-military, informational means ${ }^{5}$. This initiative became an important part of the Russian "hybrid" war.

In the presented documents, Russia tries to influence the political environment in Georgia and change the western vector of the country's development through complex methods.

Russia actively uses methods of direct and indirect impact in influencing political actors, as well as the media and non-governmental organizations. These methods include supporting their supporters through financial and other means, as well as discrediting the Western political course and generating myths.

The narratives of Russian propaganda in Georgia are mainly represented by three dominant viewpoints, which are constantly heard by the pro-Russian media: 1 . Religion as a basis for unity; 2 . National identity public discourses based on historical past and shared values, and 3. Cultural proximity - the experience of unified cultural processes. Each of these narratives has its own "medium" (respectively - part of the clergy, anti-Western political forces, and part of the Soviet intelligentsia), although the actors of public discourse usually operate equally with all three of them. Based on these narratives, a whole series of political myths is created and generated, which aims, on the one hand, to establish the messianic role of Russia (or its leader) and, on the other hand, to diminish the Western political system and values, these myths are:

1. The West is fighting the Georgian Orthodox faith and traditions; This myth is the main argument of the propaganda produced by the anti-Western forces, which is addressed with equal intensity and success by

\footnotetext{
${ }^{1}$ Malashkhia, Sh. (2011). Anatomy of Conflicts. Tbilisi.

${ }^{2}$ Joseph, S., Nye, Jr. (2004). Soft Power: The Means to Success in World Politics. Published in the United States by PublicAffairs, 96.

${ }^{3}$ Amilakhvari, L. (2017). Features of Georgian Democracies. Tbilisi.

${ }^{4}$ Rondeli, A. (2014). "Moscow's Information Campaign and Georgia." Opinion Paper, Georgian Foundation for Strategic and International Studies <www.gfsis.org/publications/view-opinion-paper/29> (2021, March, 10); Sirbiladze, I. (2019). "Russia's Disinformation Campaigns in Georgia: A Study of State and Civil Society Response". PMC Research Center, 6. <www.pmcresearch.org/policypapers_file/f6ac5dfb34c12e31c.pdf> (2021, March, 10). ${ }^{5}$ Dzhlukhidze, G. (2018). Russian propaganda-goals, narratives and actors. Tbilisi, 3.
} 
a certain part of politicians, clergy, and public figures, and which is actively propagandized by the antiWestern/pro-Russian media and non-governmental organizations. The existing discourse on this topic is often imbued with homophobia and hate speech. It often targets social and national minorities such as the LGBT community, Muslims, Turks, Jews, Armenians, and so on.

2. Russia is the key to Georgia's economic development and population well-being; Proponents of this myth have been trying to persuade the population that European Union is trying to destroy Georgia's industry and agriculture and turn the country into a market for its products.

3. The West supports specific forces and not the Georgian state; This is an extremely dangerous myth, which unfortunately has a significant base of adepts. Its propagandists take separate statements from individual European and American politicians, political groups, and experts, often without proper context, and represent as official positions of the West or Western states. In the absence of political experience or relevant knowledge, statements made by Western politicians are often represented as they show support for the former government of Georgia.

4. The myth of the invincibility of Russia/the invincibility of the Russian ruler. According to this myth, the world is bipolar, ruled by two superpowers - America and Russia. One variant of this myth is the myth of Putin as a super-leader, who established order in his country and is now fighting for world order. According to this myth, the West is ruled by weak, feeble leaders who can not cope with the problems of the modern world, but the Russian leader is characterized by agility, resilience, and probity.

5. The West will never accept Georgia into NATO and the EU.

6. Europe and America demand the legalization of same-sex marriage in Georgia. This, at first glance, unreasonable myth is very popular in the religious and nationalist radical circles of Georgia. Propagandists of this myth often cite the example of Russia, which unanimously passed a federal law in June 2013 banning LGBT propaganda. The situation has become so dramatic that EU Commissioner for Enlargement and European Neighborhood Policy Stefan Fule has called for a special explanation and made it clear that the EU does not want Georgia to legalize same-sex marriage.

The reason for the generation of myths and their success is that they are often ideally compatible with the phobias prevalent in large sections of the population and the complexes established by Soviet propaganda. The powerful emotional and, at the same time, the irrational effect of the myth allows anti-Western propaganda organizers to take political discourse to a qualitatively different level, against which the conventional method of information protection does not work.

Russia's influence and propaganda have intensified since 2014, as a result of the Ukrainian revolution and the intensification of the Eastern Partnership policy by the European Union. Propaganda has been particularly active in some sections of the Georgian print media in the form of anti-Western and anti-American calls, the establishment of stereotypes and encouragement of radicalism, and internet "trolls" and "blogs" in which the Kremlin seeks to direct the discussion on the Internet in its favorable direction. It is noteworthy that special websites for combating propaganda and campaigning have been set up on the Internet by initiative groups in both Ukraine and Georgia. On the Georgian website www.damoukidebloba.ge information about Russian state propaganda, occupation, repression, and other open or indirect forms of aggression is posted and constantly updated, which constantly allows the general public to protect themselves from misinformation spread by Russia and to get acquainted with verified and qualified information.

Richard Lugar Public Health Research Center was the target of Russian propaganda and disinformation campaigns before COVID-19 Pandemic ${ }^{1}$, with the outbreak of the pandemic, the Russian state apparatus more seriously attacked the Lugar laboratory and made the existence of a laboratory near the Russian border a security issue ${ }^{2}$.

There is a growing debate in the international arena about developing appropriate response mechanisms to existing challenges.

In March 2015, NATO presented an interim study that clearly outlined the risks faced by the international community in dealing with Russia's propaganda activities. In May 2019, a joint document of the US Department of Defense and the Joint Chiefs of Staff was published - White Paper,

\footnotetext{
${ }^{1}$ Hamilton, D. S., Meister, S. (eds.) (2016). The Eastern Question: Russia, the West and Europe's Grey Zone. Washington, DC: Center for Transatlantic Relations.

${ }^{2}$ Gelava, S. (2016). Disinformation by Global Research Center in Alia Regarding the Lugar Laboratory. Myth Detector <www.mythdetector.ge/en/ myth/disinformation-global-research-center-alia-regarding-lugar-laboratory> (2021, March, 10).
} 
entitled "Russia's Strategic Intentions - Multilateral Strategic Assessment"1 ${ }^{1}$. In the form of excerpts, it contains especially important assessments and information for Georgia, which responds to the security context of our country.

Along with the political statements, active discussions on specific steps have also begun. In March 2015, the Council of Europe set up a special panel of experts to work intensively against propaganda. Through a social network and a special portal, the group publishes weekly reports on disinformation and propaganda. In 2015-2017, the US allocated \$ 10 million annually to assist Georgia, Ukraine, and Moldova in the fight against Russian propaganda, and the US budget for 2021 provides $\$ 308$ million to strengthen the security of countries on Europe's eastern and southern borders and "overcome Russia's harmful influence" 2 . Besides, funding for American radio stations "Radiotavisupleba" and "Amerikis khma" for broadcasting in Crimea and the rest of Ukraine has increased ${ }^{3}$. Also, important global context is that in addition to the recent fight against propaganda, the international community has used international sanctions due to Russia's growing aggressive policy, and at the same time - the world market is experiencing a downward trend in oil prices; If we add to this the local factor, according to which the estimated age of the main target group of the Russian soft power is middle age and old age, we can assume that the growth of Russian influence is expected only in the medium and short term, But in the long term perspective, with the emergence of a new generation and elites and the consolidation of the international community against Russia's imperial policy, its influence will gradually be limited. But this requires our country to pursue the right policy to face existing threats and challenges - effectively develop and implement strategies for Euro-Atlantic integration and de-occupation based on the opportunities created, to develop an effective institutional and legal framework for the creation and implementation of state security policy and to establish an effective practice.

\section{References:}

1. Berdyayev, N. (1971). Russkaya ideya [Russian idea]. Paris. [in Russian].

2. Dostoevsky, F.M. (1884). Polnyy sbornik sochineniy [Complete collection of works.] Moscow, 27. [in Russian].

3. Tsereteli, A. (1990). Records in five volumes. Tbilisi, V. [in English].

4. Dundua, S. (2001). Liberal Democracy and the State Building Process in Contemporary Georgia. Tbilisi. [in English].

5. Javakhishvili, I., Surguladze, P. (1989). List. Historical parity. Tbilisi. [in English].

6. Asmus, D. (2010). A Little war that shook the world. Tbilisi. [in English].

7. Malashkhia, Sh. (2011). Anatomy of Conflicts. Tbilisi. [in English].

8. Joseph, S., Nye, Jr. (2004). Soft Power: The Means to Success in World Politics. Published in the United States by PublicAffairs. [in English].

9. Amilakhvari, L. (2017). Features of Georgian Democracies. Tbilisi. [in English].

10. Rondeli, A. (2014). "Moscow's Information Campaign and Georgia." Opinion Paper, Georgian Foundation for Strategic and International Studies <www.gfsis.org/publications/view-opinion-paper/29> (2021, March, 10). [in English].

11. Sirbiladze, I. (2019). "Russia's Disinformation Campaigns in Georgia: A Study of State and Civil Society Response. PMC Research Center, 1-45 <www.pmcresearch.org/policypapers_file/f6ac5dfb34c12e31c.pdf> (2021, March, 10). [in English].

12. Dzhlukhidze, G. (2018). Russian propaganda - goals, narratives and actors. Tbilisi. [in English].

13. Hamilton, D. S., Meister, S. (eds.) (2016). The Eastern Question: Russia, the West and Europe's Grey Zone. Washington, DC: Center for Transatlantic Relations. [in English].

14. Gelava, S. (2016). Disinformation by Global Research Center in Alia Regarding the Lugar Laboratory. Myth Detector <www.mythdetector.ge/en/ myth/disinformation-global-research-center-alia-regarding-lugar-laboratory> (2021, March, 10). [in English].

15. TASS (2020). US Labs in Third Countries May be Developing Pathogenic Agents - Diplomat <www.tass.com/politics/1146327> (2021, March, 10). [in English].

16. Bilanishvili, G. (2019). Russian Strategic Intentions <https://www.gfsis.org/publications/view/2716> (2021, March, 10). [in English].

\footnotetext{
${ }^{1}$ TASS (2020). US Labs in Third Countries May be Developing Pathogenic Agents - Diplomat <www.tass.com/politics/1146327> (2021, March, 10).

${ }^{2}$ Bilanishvili, G. (2019). Russian Strategic Intentions <https://www.gfsis.org/publications/view/2716> (2021, March, 10).

${ }^{3}$ Gabidzashvili, I. (2019). Disinformation as if the United States Provides Only Military Aid to Georgia, 24.

Myth Detector <http://www.mythdetector.ge/en/myth/disinformation-if-united-states-provides-only-military-aid-georgia> (2021, March, 10).
} 
17. Gabidzashvili, I. (2019). Disinformation as if the United States Provides Only Military Aid to Georgia. Myth Detector <http://www.mythdetector.ge/en/myth/disinformation-if-united-states-provides-only-military-aid-georgia> (2021, March, 10). [in English].

18. The Liberal Academy Tbilisi Foundation (2016). Policy Paper, Threats to Russian Hard and Soft Power in Georgia

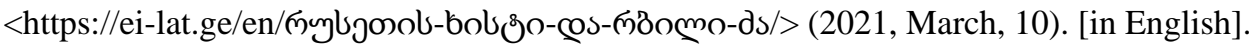

